\title{
THE IMMEDIATE EFFECT OF MONETARY UNION ON EU-15 SOVEREIGN DEBT YIELD SPREADS
}

\author{
Marta Gómez-Puig* \\ Universitat de Barcelona \\ July 2008
}

\begin{abstract}
Yield spreads (corrected for exchange rate risk) over 10-year German securities of European Union countries that did not join EMU experienced an average decrease of 14.20 basis points during the first three years after the beginning of Currency Union. Conversely, Euro-area countries' adjusted spreads registered an average rise of 11.98 basis points in the same period. This paper examines the elements (a possible change in the relative importance of domestic or international risk factors) behind these results using both panel estimations in the two groups of countries and a country-by-country specification in each of them.
\end{abstract}

JEL Classification Numbers: E44, F36, G15.

Keywords: Monetary integration, sovereign securities markets, international and domestic credit risk, and market liquidity.

\footnotetext{
* Departament de Teoria Econòmica. Universitat de Barcelona. Av. Diagonal 690, Barcelona 08034. Spain. T: 34-934.020.113.
} Fax: 34-934.039.082. E-mail: marta.gomezpuig@ub.edu ) 


\section{Introduction}

Two of the main factors that determined yield differentials in EMU participating countries were eliminated with the introduction of a common currency in January 1999 and the elimination (or reduction to insignificant levels) of differences in tax treatment during the 1990s. This fact implied and increase in both the degree of substitution between issues and in the relevance of credit risk and market liquidity differences in their yield spreads ${ }^{1}$. Nevertheless, segmentation did not disappear completely. The persistence of yield differentials is a clear example of it. With this regard, from our sample, which is composed of daily data from January 1996 to December 2001, we can draw the following conclusions. Certainly, in EMU-countries, table 1 shows an increase in the correlation coefficient between their yields and those of Germany with the beginning of Currency Union. This convergence in total yield differentials over 10-year German bond yields during the aforementioned period is displayed in table 2a. Conversely, the three European Union countries that did not participate in the EMU, outside the increased competition between Euro-area markets, seem to have benefited from both a lower assessment of their risk premium and a higher assessment of their particular "idiosyncrasies" by market participants. This has attracted to their markets investors who wished to reduce their portfolio risk through the diversification of their investments. Table 1 shows that the correlation coefficient between non-Euro and Germany yields registered a substantial decrease since the introduction of the euro and, on average, these countries experienced a spread reduction which is more than twice that registered by Euro-countries (see table 2a).

The main objective, in this paper, is to extend the analysis presented in Gómez-Puig (2008) to the European Union countries that did not participate in the EMU. So, the sample will then include all EU-15 countries (with the exception of Luxembourg and Greece and) and in order to compare the results with those we obtained for the participant countries, we will analyze the same period: 1996-2001 as in our previous papers: Three years before and three years after the introduction of the euro. As in our earlier papers, the analysis in this paper will also be threefold: First, in order to have homogeneous series throughout all the sample for non-Euro and Euro participating countries, in which exchange rate risk was removed in 1999, we follow Favero, Giavazzi and Spaventa (1997) and correct yield spreads from the exchange rate factor (during the period 1996-1999 in EMU-countries and in the whole period in nonEMU countries) by estimating the foreign exchange factor as the differential between the 10 year swap rate in the currency of denomination of the bond and the 10 year swap rate in Deutsche marks ${ }^{2}$. Then, we break down yield spreads into their two main domestic components not related to exchange risk. Second, we examine whether there was a change in the price assigned to them by markets after the introduction of the Euro which might explain the observed yield spread behavior. Third, we examine the effects of

\footnotetext{
1 The introduction of the euro also implied a strong sovereign bond market growth which, as de Bondt and Lichtenberger (2004) point out, has also been translated to the corporate bond market and has benefited economic activity in the euro area.

2 This correction is broadly explained in Gómez-Puig (2008).
} 
international risk factors on yield differentials. The main goal of the analysis is to identify the possible factors behind the immediate effect of EMU on EU-15 sovereign yield spreads. In particular, the average decrease of 14.20 basis points in non-Euro yield spreads during the first three years of Monetary Union (once they are corrected from the exchange rate factor), compared to the average increase of 11.98 basis points observed in EMU-countries.

We present the results of two different specifications which are the ones that presented the highest explanatory power in our previous studies. Therefore we implement (I) a static panel regression ${ }^{3}$, and (II) a static regression for each individual country which includes the same explanatory variables as in the panel estimation. The empirical evidence shows that the relevance of international risk factors in explaining the observed change in adjusted spreads is larger in non-Euro participating countries than in Euro-area countries. The fact that these countries kept their Monetary Autonomy might explain this greater vulnerability to external risk factors ${ }^{4}$. However, the results of all the specifications are highly consistent, providing evidence that in all European markets market size scale economies increased with Currency Union and that the rise was higher in smaller debt markets ${ }^{5}$. Hence, they suggest that the removal of the exchange rate barrier might have penalized EMU small markets twice. First, within the Euro-area, the German market could have concentrated the majority of the trading activity, and in the current context of increased competition between these markets, their relative success might be dependent on their size. And, second, outside the Euro-area, the Currency Union has enhanced the "singularity" of the debt markets because their securities are still denominated in their own currency. In particular, the British market, which before EMU not only was one of the most important European debt markets, but also was the European market that held the highest share of foreign assets as a function of total financial wealth (see Tesar and Werner 1995), is surely the one that has capitalized most on this new advantage and has attracted a significant volume of funds. The rest of the paper is organized as follows: Section 2 outlines evidence concerning Monetary Integration in Europe and the evolution of the relative cost of borrowing in EU-15 countries. Section 3 focuses on the various domestic and international factors to which adjusted spreads might be sensitive, and describes the data. Section 4 explains the models and estimation methodology. Section 5 reports the results. Lastly, section 6 draws conclusions.

\section{Monetary integration and the relative cost of borrowing in EU-15: Some evidence.}

If we analyze the spread behaviour of non-EMU participating countries in the first three years since the introduction of the Euro we observe huge differences with EMU-countries. Figure 1 shows that, for the former, the spread reduction is more than twice that registered by Euro-countries. In particular, the

\footnotetext{
3 In Gómez-Puig (2008), we estimated a dynamic model but the introduction of a lag of the dependent variable did not improve the results.

${ }^{4}$ Nevertheless, it is important to note that, although EMU countries do not have monetary policy autonomy, they do not present the same response pattern to ECB decisions (see Clausen and Hayo, 2006).

${ }^{5}$ In Gómez-Puig (2006) we deeply analysed the effect of market size on liquidity.
} 
average spread over German yields decreased by 73.06 basis points in the EMU period (see table 2) in the three non-Euro countries as a whole. On the other hand, the swap differential behaviour clearly differs. The different pattern that it already showed before the Euro (see figure 2) has been accentuated after Currency Union and the close convergence to zero of swap differentials among Euro-countries. Hence, the temporal evolution of the adjusted spread presents a completely different picture for non-Euro countries after January 1999 (see figure 3) and its average value has also decreased: 14.20 basis points on average between the two periods. Actually, it clearly decreases in Sweden and the United Kingdom (the two countries that really kept a floating exchange rate regime), while it experiences a slight increase in Denmark (0.31 basis points). It has to be noted that Denmark is not only the non-Euro country with the smallest debt-market (see table 3), but that its exchange rate also maintained a link with the Euro; consequently its adjusted spread behaviour is quite similar to that of the Euro-zone countries.

Therefore, in a context of higher integration between European markets, with the exception of Denmark, the countries that did not join Monetary Union seem to have benefited from that fact in terms of an important decrease in their risk premium over Germany (not related to exchange rate factors), which has resulted in lower borrowing costs. The main goal of this paper will be to find an explanation for the different behaviour that yield spreads experienced in the two groups of countries during the first three years of EMU. One possible explanation could be that, in the current context of increased competition between Euro-area government securities markets, their success might be limited by the extent of their liquidity and market size. Specifically, on the one hand, as the German sovereign debt market is the second largest in the Euro-area (only surpassed by the Italian), a concentration of trading activity in the German market might have occurred and, consequently, wider liquidity differences vis-à-vis German bonds might have been translated into higher adjusted spreads in EMU-participating countries ${ }^{6}$. Nevertheless, on the other hand, the British sovereign debt market not only is the fourth largest in the European Union-15 area (see table 3) but, since Monetary Integration, has also benefited from a new advantage over Euro-area debt markets because its debt is still denominated in a different currency which allows portfolio diversification and risk reduction. Therefore, since EMU the British market might have capitalized on its role as the main competitor to the German market, and might have attracted funds from those investors who wished to reduce their risk by investing in a market that still permits portfolio diversification. Consequently, with the Euro the small-size Euro-area debt markets might have been twice penalized. First, within the Euro-area, the German market could have concentrated the majority of the trading activity. And, second, outside the Euro-area, the enhanced British market might have attracted a significant volume of funds due to its "renewed" singularity.

\footnotetext{
${ }^{6}$ The existence of a very liquid futures bond market in Germany also represents an additional advantage of holding German bonds.
} 
Some literature supports the importance of market size in the success of a debt market. McCauley and Remolona (2000) note that if substantial fixed costs are involved in the production of information about the future path of interest rates, the size of the whole debt market matters. They calculate that there may be a size threshold around $\$ 100-200$ billions; below this level, they state that sustaining a liquid government market may not be easy. Table 3 shows that while in the Euro-area only five countries (Italy, Germany, France, Spain and Belgium) surpassed that threshold, in the non-Euro-area two countries did (Sweden and the United Kingdom) and the third (Denmark) came close ${ }^{7}$. Economides and Siow (1988) point out that there may be a trade-off between liquidity and market size: the smaller the market, the lower the outstanding volume traded in it and the more difficult it will be for investors to process and evaluate information about securities traded in that market, which would imply higher transaction costs and liquidity premium. Hence, if size matters for liquidity, "ex-ante" traders would prefer bigger and liquid markets and liquidity will be selffulfilling. On the other hand, another point that is important to assess is whether the too big to fail theory (TBTF), taken from the banking system (see Kaufman, 2002) might also hold in sovereign debt markets; if it does apply, the removal of the exchange rate barrier would have punished smaller countries by making them pay both a higher liquidity and higher default risk premium than large ones.

\section{Domestic and international risk factors explaining adjusted yield spreads.}

Now that we have defined the dependent variable $\left(A S P R E A D_{i t}\right)$ which allows separation of risk components not related from expected exchange-rate depreciation, decomposition between domestic is attempted by modelling their behaviour to a number of factors that potentially affect only one of them. With regard to domestic risk factors, a crucial issue in this paper (and one that is vital for policymaking) is the identification of the two main domestic sources of risk that have made up yield spreads in EU-15 countries since the start of Monetary Integration: (1) differences in credit risk and (2) differences in market liquidity, in order to assess whether their impact over yield spreads has changed with the common currency. With this goal in mind, the relative debt-to-GDP ratio will be used as a proxy to measure differences in credit risk. This variable has been widely used in the literature by other authors and presents the advantage over other measures such as the rating differential that it cannot be considered an ex-post measure of fiscal sustainability. As in Gómez-Puig (2008), two different proxy variables will be used to measure the market liquidity effect: (i) the bid/ask spread and (ii) the on-the run/off-the run spread. Lastly, a third point that will be assessed in this paper is the influence of international risk factors on yield spreads. Hence, the spread between 10-year fixed interest rates on US swaps and the yield on 10-year Moody's Seasoned AAA US corporate bonds is introduced in the model as a proxy of international risk factors.

\footnotetext{
7 Within the Euro-area: Austria, Finland, Greece, Ireland, and Portugal present an overall amount of public sector outstanding debt below the $\$ 100$ billion level, while The Netherlands entire amount of outstanding public debt is between $\$ 100$ and $\$ 200$ billions. Outside the euro-area: only Denmark presents an amount slightly below the $\$ 100$ billion level.
} 
As defined, the dependent variable is $A S P R E A D_{i t}$, i.e. the difference between the total yield differential of 10-year government bonds and the 10-year interest rate swap differential. The sample comprises daily data spanning the period January 1, 1996 to December 31, 2001. Yields and swap rates are obtained from Datastream and correspond to the benchmark 10-year issue for each market at every moment of time. As a benchmark changes, data are taken from a new stock on the first day of the month ${ }^{8}$. With regard to the $\mathrm{bid} /$ ask spreads and the on-the-run/off-the-run series, daily time-series have been created using data collected from Bloomberg. The overall outstanding amounts of public debt data have been drawn from the Bank for International Settlements (BIS; see table 3) and the GDP from Eurostat. And finally, the spread between 10-year fixed interest rates on US swaps and the yield on 10-year Moody's Seasoned AAA US corporate bonds (USSPREAD $D_{i t}$ ), has been calculated from daily data obtained from Datastream. All the variables included in the estimation that capture domestic risk factors are in relative terms to the German ones, as our dependent variable $\left(A S P R E A D_{i t}\right)$ is the difference between the total yield differential and the swap differential of country $i$ over Germany.

\section{Modeling adjusted yield spread behavior.}

We will present the results of two different specifications which are the ones that presented the highest explanatory power in our previous studies? ${ }^{9}$ Therefore we will first implement (I) a static panel regression, and (II) a static regression for each individual country which will include the same explanatory variables as in the panel estimation. Therefore, model I will be a panel regression with both domestic and international risk variables:

$y_{i t}=\alpha_{i}+\beta X_{i t}+\gamma D P R E_{i t}+\delta M O N T H L Y D U M M I E S_{t}+\lambda C O U N T R Y D U M M I E S_{i}+\varepsilon_{i t}$

Where, with the international $\left(\mathrm{IR} V_{i t}\right)$ and domestic risk variables $\left(D R V_{i t}\right)$ previously defined, the vector of independent variables will be:

$X_{i t}=\left(\operatorname{IRV} V_{i t} D R V_{i t} D R V_{i t}^{*} \operatorname{IR} V_{i t}\right)$

In addition

$\beta=\beta_{1}+\beta_{2} D P R E_{i t}$

Finally, in model II, using the same independent variables as in the panel regression, a static estimation will be implemented separately for each of the three non-Euro countries in the sample. The estimation methods used in all specifications, Feasible Generalized Least Squares (FGLS) in the panel estimation and a regression with Newey-West standard errors in the estimations for each non-Euro-country, are robust to the possible existence of autocorrelation and heteroscedasticity in the error terms.

\footnotetext{
8 Table 4 presents the starting benchmark dates used by Datastream as well as the characteristics of the different benchmarks that compose the yield and swap series for non-EMU participating countries, whilst the references used in the case of euro-participating countries are described in Gómez-Puig (2008).

${ }_{9}^{9}$ These specifications are broadly explained in Gómez-Puig (2006 and 2008).
} 


\section{Results.}

Tables 5 and 6 present respectively, the values and standard errors of the estimated coefficients corresponding to the first and second specifications. In particular, table 5 presents the results for the static panel regression and, in order to compare the results, also introduces the results obtained from the same panel regression when it was applied to the Euro-participating countries (see Gómez-Puig, 2008) ${ }^{10}$. Because of their length, monthly and country dummy variables' coefficients are not presented, although monthly dummies are significant in the majority of the periods. As for the country dummies, all of them are significant. Specifically, the panel regression for non-Euro countries shows that not only does the default risk premium not increase with Currency Union but its marginal impact becomes negative with the Euro. Even so, the increase in the EMU period of the marginal impact of the interaction of the default risk proxy with the international risk factor qualifies to some extent the previous results. Actually, what seems to be relevant is the increase in the marginal effect of the international factor which, in addition, is higher than the one we obtained for Euro-countries. Finally, with regard to the variables that capture liquidity risk, we should note that not only its marginal impact increases with the Euro, but also shows a non-linear behaviour that supports the self-fulfilling behaviour of liquidity. Table 6 presents the results of the country-specific estimations for the non-Euro countries. In the case of the British market we should point out that all the explanatory variables used in the regression lose their significance in the EMU period. Therefore, variables other than those used as proxies of domestic risk or international risk must explain the decrease of the 10-year adjusted spread over Germany in the EMU period. In our opinion, one possible explanation could be a flight of funds from small Euro-area debt markets to the enhanced British debt market which not only is big enough to be liquid by itself, but, since the introduction of the common currency, presents an additional advantage in terms of allowing portfolio diversification, since its securities are not denominated in Euros. In the Swedish market we should also mention the decrease in the marginal impact of the default risk variable in the EMU period, in spite of its very high debt-to-GDP ratio. Hence, it seems that the default risk might be compensated by its increased liquidity, both because it has a "relevant" size (which could reduce the importance of default risk as long as agents believe that it is "too big to fail") and because its singularity has increased since Monetary Union. The increase in the significance of the non-linear term of the bid-ask spread since EMU supports the self-fulfilling nature of liquidity and is in concordance with the rest of the results. Finally, Denmark, the only non-Euro participating country that has experienced a slight increase of its adjusted spread over Germany with the Euro, is precisely the one whose exchange rate does not float and with the smallest debt-market. This seems to support the theory that big markets are the ones that have experienced the most benefits from Monetary Integration. Actually, the marginal impact of the non-linear term of both liquidity proxies

\footnotetext{
10 In the case of EMU-countries, we only show the results for the first specification, which have been drawn from Gómez-Puig (2008).
} 
registers an increase in the EMU period when it is interacted with the international risk proxy. This result supports the increasingly nature of illiquidity in the case of a small-debt market such as the Danish market.

\section{Conclusions}

The immediate effect of Currency Union on EU-15 sovereign yield spreads can be summarized as follows. Non-Euro participating countries' adjusted spreads experienced an average decrease of 14.20 basis points with Currency Union. Conversely, Euro-area countries' adjusted spreads over 10-year German securities registered an average rise of 11.98 basis points in the first three years of EMU. Therefore, in a context of higher integration between European markets, the countries that did not join Monetary Union, and thus did not experience an increase in their degree of substitutability and competition with German securities, seem to have benefited from that fact, in the shape of an important decrease in their risk premium that has resulted in lower borrowing costs. However, while in Euro-area markets a change in the market assessment of domestic rather than international risk factors might be behind the increase observed in adjusted spreads with Monetary Integration; as mentioned, in non-Euro participating countries, the importance of international risk factors in explaining adjusted spread changes is higher. The fact that these countries do not share the European Central Bank monetary policy, which main goal is achieving price stability, might explain this greater vulnerability to external risk factors ${ }^{11}$. The results of all specifications are very consistent. They provide evidence that market size scale economies seem to have increased with Currency Union and that the smaller the debt market, the higher the rise. Actually, since January 1999 the adjusted spread over 10-year German bonds has increased in all Euro-area countries and in the non-Euro participating country (Denmark) that presents the smallest debt market and whose exchange rate is still linked to the Euro, and table 3 shows that the German market is the second biggest in the Euro-area. Hence, on the one side, an improvement of relative German market liquidity might be behind the adjusted spread changes. In fact, within the Euro-area, the countries with a larger debt market relative to Germany (Italy, France and Spain) are the ones that have experienced the lowest rise in their adjusted spreads with the introduction of the Euro (see table $2 \mathrm{~b}$ ). On the other hand, outside the Euro-area, the enhanced British market might also have attracted a significant volume of funds due to its "renewed" singularity which still allowed investors to reduce their risk investing in a market where debt is denominated in a different currency. Hence, the British market might have capitalized on its role as the German market's main competitor. To conclude, with the introduction of a common currency and in the current context of higher competition between Euro-area government securities markets, the success of these sovereign

\footnotetext{
${ }^{11}$ Altavilla and Landolfo (2005) analyze whether the ECB and the Bank of England have a different behaviour during recession and expansion. They results confirm that whilst the primary goal of the ECB consists of achieving price stability, the Bank of England contemporaneously targets output and inflation.
} 
securities debt markets may be highly dependent on their market size (the removal of the exchange rate barrier seems to have punished Euro-area smaller markets twice, by making them pay both higher liquidity and a higher default risk premium than larger ones). In the case of non-Euro participating countries: on the one hand, since they did not suffer the increase in their degree of substitutability and competition mentioned above, they seem to have benefited from the fact that market participants consider their risk premium to be low and the investment advantages to be high and; on the other, the maintenance of their monetary autonomy might be related with their higher vulnerability to external risk factors.

\section{Acknowledgments}

I thank the participants in all the seminars where the paper has been presented for their useful comments. I would also like to thank Analistas Financieros Internacionales, S.A. who have kindly provided part of the data used in the empirical analysis. Special thanks to Jordi Galí and Jaume Ventura, for their insightful comments on previous versions of the paper. I alone am responsible for any errors remaining in the final version.

\section{References}

Altavilla, C. and L. Landolfo, 2005. Do central banks act asymmetrically? Empirical evidence from the ECB and the Bank of England. Applied Economics, 37, pp.507-519.

Codogno, L., C.Favero and A. Missale, 2003. EMU and Government Bond Spreads. Economic Policy n.18, pp.503-532.

Clausen, V. and B. Hayo, 2006. Asymmetric monetary policy effects in EMU. Applied Economics, 11, pp. 1123-1134.

De Bondt, G. and J-D. Lichtenberger, 2004. Sovereign Empirical estimates of the impact of the euro on the corporate bond market in the euro area. Applied Economics, 11, pp. 675-678

Economides, N. and A.Siow, 1988. The Division of Markets is Limited by the Extent of Liquidity (Spatial Competition with Externalities). American Economic Review, Vol.78, n¹ pp 1719-1734.

Favero, C., F. Giavazzi and L. Spaventa, 1997. High Yields: The Spread on German Interest Rate. The Economic Journal, Vol.107, Issue 443.

Gómez-Puig, M., 2006. Size Matters for Liquidity: Evidence from EMU sovereign yield spreads. Economics Letters, Vol.9, Issue 2; pp.156-162, February.

Gómez-Puig, M. 2008. Monetary Integration and the Cost of Borrowing. Journal of International Money and Finance, Vol 27/3, pp.455-479.

Kaufman, G.G. 2002. Too big to fail in banking: What remains?. The Quarterly Journal of Finance n. 42, pp.423-436.

McCauley R. and E.Remolona, 2000. Size and Liquidity of Government Bond Markets. BIS Quarterly Review, November.

Tesar, L. and I. Werner, 1995. Home bias and high turnover. Journal of International Money and Finance, Vol.14, N4, pp.467-492. 


\section{FIGURE 1}

10 YEARS YIELD SPREADS OVER GERMANY

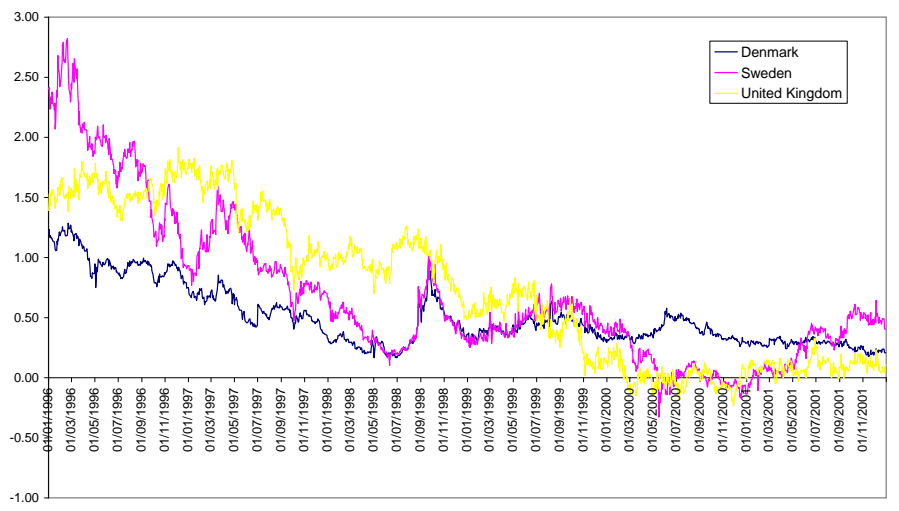

NOTE: Yield differential $=\left(I_{i}-I_{D M}\right)$, where $I_{i}$ is the 10-year yield on country i government bonds and $I_{D M}$ is the 10-year yield on Germany government bonds.

Source: Datastream

\section{FIGURE 2}

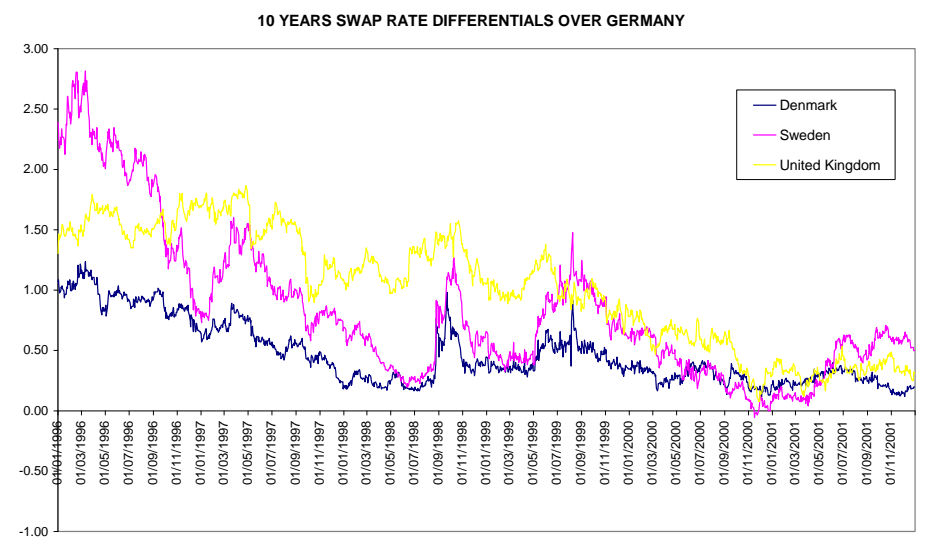

NOTE: Swap differential $=\left(\operatorname{IRS}_{\mathrm{i}}-\mathrm{IRS}_{\mathrm{DM}}\right)$, where $\mathrm{IRS}_{\mathrm{i}}$ is the 10 -year interest rate swap of currency $\mathrm{i}$ and $\operatorname{IRS}_{\mathrm{DM}}$ is the 10 -year interest rate swap of the D-mark.

Source: Datastream

\section{FIGURE 3}

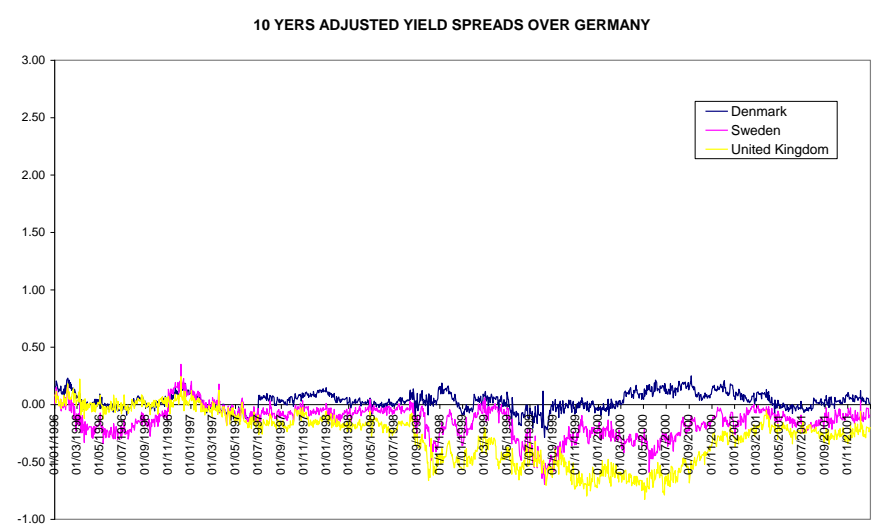

NOTE: Adjusted yield spread $=$ Yield differential - Swap differential $=\left(\mathrm{I}_{\mathrm{i}}-\mathrm{I}_{\mathrm{DM}}\right)-\left(\mathrm{IRS}_{\mathrm{i}}-\mathrm{IRS}_{\mathrm{DM}}\right)$. Source: Datastream. 
TABLE 1

\begin{tabular}{|c|c|c|}
\hline \multicolumn{3}{|c|}{ Correlation Coefficient with 10-Year German Yields } \\
\hline & pre-EMU(1996-1998) & EMU(1999-2001) \\
\hline EURO & & \\
\hline AT & 0,99 & 0,97 \\
BE & 0,99 & 0,97 \\
FI & 0,97 & 0,99 \\
FR & 0,98 & 0,97 \\
IE & 0,97 & 0,98 \\
IT & 0,90 & 0,98 \\
NL & 0,99 & 0,99 \\
PT & 0,91 & 0,90 \\
SP & 0,90 & 0,98 \\
\hline Average & $\mathbf{0 , 9 6}$ & $\mathbf{0 , 9 7}$ \\
\hline & & \\
\hline Non-EURO & & \\
\hline DK & 0,98 & 0,99 \\
SW & 0,92 & 0,61 \\
UK & 0,89 & 0,95 \\
\hline Average & $\mathbf{0 , 9 3}$ & $\mathbf{0 , 8 5}$ \\
\hline
\end{tabular}

TABLE 2a

\begin{tabular}{|c|c|c|c|c|c|c|}
\hline & \multicolumn{3}{|c|}{ PRE-EMU (1996-1998) } & \multicolumn{3}{|c|}{ EMU (1999-2001) } \\
\hline & $\left(\mathrm{l}_{\mathrm{i}}-\mathrm{I}_{\mathrm{DM}}\right)$ & $\left(\mathrm{IRS}_{\mathrm{i}}-\mathrm{IRS} \mathrm{SM}_{\mathrm{DM}}\right)$ & ASPREAD $_{\mathrm{i}}$ & $\left(\mathrm{l}_{\mathrm{i}}-\mathrm{I}_{\mathrm{DM}}\right)$ & $\left(\mathbf{I R S}_{\mathrm{i}}-\mathbf{I R S} \mathrm{DM}_{\mathrm{DM}}\right)$ & ASPREAD \\
\hline & (1) & (2) & $(3)=(1)-(2)$ & (4) & (5) & $(6)=(4)-(5)$ \\
\hline \multicolumn{7}{|l|}{ EURO } \\
\hline AT & 9.07 & -0.33 & 9.40 & 24.42 & -0.01 & 24.43 \\
\hline BE & 33.06 & 4.29 & 28.77 & 46.30 & -0.01 & 46.31 \\
\hline $\mathrm{FI}$ & 43.56 & 41.31 & 2.25 & 21.95 & -0.01 & 21.96 \\
\hline FR & 2.97 & -3.10 & 6.07 & 14.05 & 0.00 & 14.05 \\
\hline IE & 50.52 & 43.84 & 6.68 & 14.78 & 0.00 & 14.78 \\
\hline IT & 157.73 & 133.04 & 24.69 & 32.32 & 0.05 & 32.27 \\
\hline NL & -2.70 & -3.52 & 0.83 & 14.22 & -0.01 & 14.23 \\
\hline PT & 111.73 & 91.42 & 20.31 & 31.85 & 0.22 & 31.63 \\
\hline SP & 118.06 & 97.99 & 20.07 & 27.24 & 0.04 & 27.20 \\
\hline Average & 58.22 & 44.99 & 13.23 & 25.24 & 0.03 & 25.21 \\
\hline St.dev. & 57.48 & 51.37 & 10.33 & 10.66 & 0.08 & 10.64 \\
\hline \multicolumn{7}{|c|}{ NON-EURO } \\
\hline DK & 64.01 & 61.09 & 2.92 & 35.83 & 32.61 & 3.23 \\
\hline sw & 108.48 & 117.15 & -8.67 & 28.14 & 49.01 & -20.87 \\
\hline UK & 129.95 & 142.05 & -12.10 & 19.27 & 62.07 & -42.80 \\
\hline Average & 100.81 & 106.77 & -5.95 & 27.75 & 47.90 & -20.15 \\
\hline St.dev. & 33.63 & 41.46 & 7.87 & 8.29 & 14.76 & 23.02 \\
\hline
\end{tabular}

TABLE 2b

\begin{tabular}{|l|cc|}
\hline \multicolumn{3}{|c|}{ Differences between EMU and PRE-EMU } \\
\hline & $\left(\mathbf{l}_{i}-\mathbf{I}_{\text {DM }}\right)$ & ASPREAD $_{\text {i }}$ \\
\cline { 2 - 3 } & $(\mathbf{4})$-(1) & $(6)-(3)$ \\
\hline EURO & & 15.03 \\
\hline AT & 15.34 & 17.53 \\
BE & 13.24 & 19.71 \\
FI & -21.61 & 7.98 \\
FR & 11.08 & 8.10 \\
IE & -35.74 & 7.58 \\
IT & -125.40 & 13.40 \\
NL & 16.92 & 11.31 \\
PT & -79.88 & 7.13 \\
SP & -90.82 & $\mathbf{1 1 . 9 8}$ \\
\hline Average & $\mathbf{- 3 2 . 9 9}$ & 4.69 \\
St.dev. & 53.77 & \\
& & \\
\hline NON-EURO & & -12.20 \\
\hline DK & -28.18 & -30.70 \\
\hline SW & -80.33 & $\mathbf{- 1 4 . 2 0}$ \\
UK & -110.68 & 15.60 \\
\hline Average & $\mathbf{- 7 3 . 0 6}$ & \\
St.dev. & 41.73 & \\
\hline
\end{tabular}

NOTE: AT: Austria, BE: Belgium, FI: Finland, FR: France, IE: Ireland, IT: Italy, NL: The Netherlands, PT: Portugal, SP: Spain, DK: Denmark, SW: Sweden and UK: United Kingdom. Source: Datastream. $\left(\mathrm{I}_{\mathrm{i}^{-}} \mathrm{I}_{\mathrm{DM}}\right)=10$-year yield difference over Germany. (IRS $\mathrm{I}_{\mathrm{i}}-$ $\left.\mathrm{IRS}_{\mathrm{DM}}\right)=10$-year interest rate swap difference over Germany. ASPREAD $\mathrm{D}_{\mathrm{i}}=\left(\mathrm{I}_{\mathrm{i}}-\mathrm{I}_{\mathrm{DM}}\right)-\left(\mathrm{IRS}_{\mathrm{i}}-\mathrm{IRS}_{\mathrm{DM}}\right)$

TABLE 3

\begin{tabular}{|c|c|c|c|c|c|c|c|c|c|c|}
\hline \multicolumn{11}{|c|}{$\begin{array}{l}\text { DOMESTIC DEBT SECURITIES } \\
\text { PUBLIC SECTOR AMOUNTS OUTSTANDING } \\
\text { (Billions of euros) }\end{array}$} \\
\hline & 1995-12 & 1996-12 & 1997-12 & 1998-12 & 1999-12 & $2000-12$ & 2001-12 & average & $\%$ over EMU & \% over EU-15 \\
\hline Ireland & 19.93 & 23.20 & 23.12 & 21.93 & 24.73 & 24.07 & 19.95 & 23.15 & 0.69 & 0.59 \\
\hline Portugal & 35.19 & 36.47 & 32.84 & 34.04 & 37.49 & 42.35 & 45.61 & 37.67 & 1.13 & 0.95 \\
\hline Finland & 33.20 & 38.15 & 41.56 & 44.28 & 45.60 & 47.70 & 46.28 & 43.39 & 1.30 & 1.10 \\
\hline Austria & 57.04 & 58.95 & 63.87 & 69.28 & 86.05 & 99.74 & 100.52 & 76.80 & 2.30 & 1.94 \\
\hline Greece & 64.10 & 79.58 & 84.47 & 84.80 & 88.43 & 96.73 & 102.20 & 87.23 & 2.62 & 2.21 \\
\hline Netherlands & 155.64 & 159.89 & 159.68 & 170.12 & 178.14 & 180.98 & 177.50 & 171.44 & 5.14 & 4.34 \\
\hline Belgium & 228.86 & 230.59 & 228.41 & 229.67 & 231.85 & 246.18 & 248.66 & 236.75 & 7.10 & 5.99 \\
\hline Spain & 211.07 & 241.63 & 259.63 & 272.41 & 287.34 & 311.04 & 299.43 & 269.56 & 8.09 & 6.82 \\
\hline France & 497.35 & 536.05 & 565.50 & 623.91 & 639.85 & 708.45 & 709.23 & 614.79 & 18.45 & 15.56 \\
\hline Germany & 676.53 & 682.74 & 699.45 & 738.75 & 767.35 & 816.77 & 790.81 & 734.97 & 22.05 & 18.60 \\
\hline Italy & 896.49 & 1022.19 & 1011.08 & 1037.09 & 1042.62 & 1088.36 & 1056.96 & 1036.69 & 31.11 & 26.23 \\
\hline EMU & 2875.40 & 3109.45 & 3169.63 & 3326.27 & 3429.43 & 3662.37 & 3597.15 & 3332.43 & 100.00 & 84.33 \\
\hline Denmark & 89.78 & 90.22 & 87.89 & 87.70 & 86.74 & 86.93 & 82.03 & 88.63 & - & 2.24 \\
\hline Sweden & 111.09 & 114.30 & 110.02 & 111.34 & 123.04 & 117.24 & 91.22 & 111.83 & - & 2.83 \\
\hline U.Kingdom & 316.49 & 373.76 & 418.68 & 396.12 & 456.97 & 475.31 & 460.79 & 418.69 & - & 10.60 \\
\hline
\end{tabular}

Source: Bank for International Settlements. 
TABLE 4

Non-EMU countries

\begin{tabular}{|l|l|l|l|l|}
\hline & Starting date as a benchmark & Name & \multicolumn{1}{|c|}{ Coupon } & Maturity date \\
\hline DENMARK & & & & \\
\hline & Jan-96 & DANSKE STAT & $19948 \%$ & $15 / 03 / 06$ \\
& Jul-97 & DANSKE STAT & $19967 \%$ & $15 / 11 / 07$ \\
& Feb-99 & DANSKE STAT & $19986 \%$ & $15 / 11 / 09$ \\
& Mar-01 & & $20006 \%$ & $15 / 11 / 11$ \\
\hline SWEDEN & DANSKE STAT & & \\
\hline & Nov-96 & SVENSKA & $19966.5 \%$ & \\
& Feb-97 & SVENSKA & $19968 \%$ & $15 / 08 / 07$ \\
& Feb-98 & SVENSKA & $19976.5 \%$ & $05 / 05 / 08$ \\
& Jul-98 & SVENSKA & $19939 \%$ & $20 / 04 / 09$ \\
& Feb-01 & SVENSKA & $200051 / 4 \%$ & $15 / 03 / 11$ \\
\hline & MNI-96 & & \\
\hline UNITED KINGDOM & May-97 & TREASURY & $07 / 12 / 06$ \\
& Oct-98 & $7.50 \%$ & $07 / 12 / 07$ \\
& Apr-99 & $7.25 \%$ & $13 / 10 / 08$ \\
& Apr-01 & TREASURY & $07 / 12 / 09$ \\
& Aug-01 & TREASURY & $5.75 \%$ & $25 / 11 / 10$ \\
& TREASURY & $6.25 \%$ & $07 / 03 / 12$ \\
\hline
\end{tabular}

Source: Datastream.

TABLE 5

\begin{tabular}{|c|c|c|c|c|}
\hline \multicolumn{5}{|c|}{$\begin{array}{c}\text { Cross-Sectional Time-Serie FGLS Regression. } \\
\text { Sample: Pre-EMU: 1996:01-1998:12 } \\
\text { EMU: 1999:01-2001:12 }\end{array}$} \\
\hline \multirow{2}{*}{$\begin{array}{c}\text { dependent variable: } A S P R E A D \\
X_{i t} \\
\end{array}$} & \multicolumn{2}{|c|}{ SPECIFICATION I (non-euro countries) } & \multicolumn{2}{|c|}{$\begin{array}{l}\text { SPECIFICATION I (euro countries) } \\
\text { (Gómez-Puig, 2006b) }\end{array}$} \\
\hline & $\overline{\beta_{1}\left(X_{i t}\right)}$ & $\beta_{2}\left(D P R E_{i t} * X_{i t}\right)$ & $\beta_{1}\left(X_{i t}\right)$ & $\beta_{2}\left(D P R E_{i t} * X_{i t}\right)$ \\
\hline$L N D E B T G D P_{i t}$ & $\begin{array}{l}-0.316^{* *} \\
(0.060)\end{array}$ & $\begin{array}{l}0.563^{* *} \\
(0.080)\end{array}$ & $\begin{array}{l}0.181^{* \star} \\
(0.008)\end{array}$ & $\begin{array}{l}-0.017^{* *} \\
(0.002) \\
\end{array}$ \\
\hline ONOFFDIF $_{i t}$ & $\begin{array}{l}1.162^{* *} \\
(0.087)\end{array}$ & $\begin{array}{l}-3.193^{\star *} \\
(0.202)\end{array}$ & $\begin{array}{l}1.782^{* *} \\
(0.104)\end{array}$ & $\begin{array}{l}-1.082^{* *} \\
(0.118)\end{array}$ \\
\hline ONOFFDIF2 ${ }_{\text {it }}$ & $\begin{array}{l}3.968^{* \star} \\
(0.516) \\
\end{array}$ & $\begin{array}{l}-2.888^{* *} \\
(0.681) \\
\end{array}$ & $\begin{array}{c}-10.686^{* \star} \\
(0.608) \\
\end{array}$ & $\begin{array}{l}5.133^{* \star} \\
(0.616) \\
\end{array}$ \\
\hline BIDASKDIF $_{\text {it }}$ & - & $\begin{array}{l}1.307^{\star *} \\
(0.475)\end{array}$ & $\begin{array}{l}0.557^{\star \star} \\
(0.050)\end{array}$ & $\begin{array}{l}-0.386^{* *} \\
(0.075)\end{array}$ \\
\hline BIDASKDIF2 ${ }_{\text {it }}$ & - & - & - & $\begin{array}{l}-2.670^{* *} \\
(0.742) \\
\end{array}$ \\
\hline USSPREAD ${ }_{i t}$ & $\begin{array}{l}0.109^{\star \star} \\
(0.021) \\
\end{array}$ & $\begin{array}{l}-0.198^{* *} \\
(0.041) \\
\end{array}$ & $\begin{array}{l}0.034^{\star \star} \\
(0.007) \\
\end{array}$ & $\begin{array}{l}-0.018^{* *} \\
(0.009) \\
\end{array}$ \\
\hline${\text { LNDEBTGDP*} U S S P R E A D_{i t}}_{\text {it }}$ & $\begin{array}{l}0.254^{* \star} \\
(0.051) \\
\end{array}$ & $\begin{array}{c}-0.845^{\star *} \\
(0.113) \\
\end{array}$ & $\begin{array}{l}0.050^{\star *} \\
(0.003) \\
\end{array}$ & $\begin{array}{c}-0.082^{* *} \\
(0.003) \\
\end{array}$ \\
\hline ONOFFDIF*USSPREAD $_{i t}$ & $\begin{array}{l}-0.802^{* *} \\
(0.109)\end{array}$ & $\begin{array}{l}4.287^{* *} \\
(0.371)\end{array}$ & $\begin{array}{l}-1.860^{* *} \\
(0.106)\end{array}$ & $\begin{array}{l}0.899^{* \star} \\
(0.145)\end{array}$ \\
\hline ONOFFDIF2*USSPREAD $_{i t}$ & $\begin{array}{l}-5.700^{* *} \\
(0.815) \\
\end{array}$ & - & $\begin{array}{l}15.425^{* *} \\
(0.720) \\
\end{array}$ & $\begin{array}{l}-6.340^{* *} \\
(0.726) \\
\end{array}$ \\
\hline BIDASKDIF*USSPREAD $_{i t}$ & $\begin{array}{l}-0.822^{*} \\
(0.430) \\
\end{array}$ & - & $\begin{array}{c}-0.401^{\star *} \\
(0.059) \\
\end{array}$ & - \\
\hline BIDASKDIF2*USSPREAD $_{\text {it }}$ & - & $\begin{array}{c}16.744^{\star *} \\
(8.372) \\
\end{array}$ & - & $\begin{array}{l}4.301^{* *} \\
(0.731)\end{array}$ \\
\hline & $\gamma$ & & $\gamma$ & \\
\hline$D P R E_{i t}$ & $\begin{array}{l}0.129^{\star *} \\
(0.032) \\
\end{array}$ & & $\begin{array}{l}0.038^{* *} \\
(0.009) \\
\end{array}$ & \\
\hline & $\alpha$ & & $\alpha$ & \\
\hline CONSTANT & - & & $\begin{array}{l}0.160^{* \star} \\
(0.005)\end{array}$ & \\
\hline $\begin{array}{l}\text { Number of observations = } \\
\text { Number of groups = } \\
\text { Avg obs per group = } \\
\text { Log likelihood = } \\
\text { Wald chi2 = } \\
\text { Prob }>\text { chi2 = }\end{array}$ & $\begin{array}{c}3402 \\
3 \\
1195.5 \\
6734.189 \\
17824 \\
0.00\end{array}$ & & $\begin{array}{c}12139 \\
9 \\
1406 \\
23893.12 \\
53337.41 \\
0.00\end{array}$ & \\
\hline
\end{tabular}

**Significant at 5 percent confidence level.

*Significant at 10 percent confidence level.

Standard Errors within parentheses 
TABLE 6

SPECIFICATION II (non-euro countries)

Regression with Newey-West Standard Errors

Sample: Pre-EMU: 1996:01-1998:12

EMU: 1999:01-2001:12

dependent variable: $A S P R E A D$

\begin{tabular}{|c|c|c|c|c|c|c|}
\hline \multirow[b]{2}{*}{$\boldsymbol{X}_{t}$} & \multicolumn{2}{|c|}{ DENMARK } & \multicolumn{2}{|c|}{ SWEDEN } & \multicolumn{2}{|c|}{ UNITED KINGDOM } \\
\hline & $\beta_{1}\left(X_{t}\right)$ & $\beta_{2}\left(D_{P R E}^{*} X_{t}\right)$ & $\beta_{1}\left(X_{t}\right)$ & $\beta_{2}\left(D P R E^{*} X_{t}\right)$ & $\beta_{1}\left(X_{t}\right)$ & $\beta_{2}\left(D P R E^{*} X_{t}\right)$ \\
\hline LNDEBTGDP $_{t}$ & - & - & $\begin{array}{l}-3.331^{\star \star} \\
(0.898)\end{array}$ & $\begin{array}{l}3.284^{\star *} \\
(0.963)\end{array}$ & & \\
\hline ONOFFDIF $_{t}$ & $\begin{array}{c}-1.191^{\star \star} \\
(0.442)\end{array}$ & - & $\begin{array}{l}7.185^{\star \star} \\
(2.568)\end{array}$ & $\begin{array}{l}-6.143^{\star *} \\
(2.644)\end{array}$ & & $\begin{array}{l}1.561^{\star \star} \\
(0.463)\end{array}$ \\
\hline ONOFFDIF ${ }_{t}$ & $\begin{array}{l}-6.539^{* *} \\
(2.856)\end{array}$ & $\begin{array}{l}11.493^{* *} \\
(3.450)\end{array}$ & $\begin{array}{c}-129.52^{\star *} \\
(56.664)\end{array}$ & $\begin{array}{l}124.94^{* *} \\
(56.651)\end{array}$ & & $\begin{array}{c}11.679^{* *} \\
(1.830)\end{array}$ \\
\hline BIDASKDIF $_{t}$ & $\begin{array}{l}2.317^{\star \star} \\
(0.981)\end{array}$ & $\begin{array}{l}3.129^{* *} \\
(1.573)\end{array}$ & $\begin{array}{l}-4.665^{\star *} \\
(0.917)\end{array}$ & - & & $\begin{array}{c}-3.492^{\star *} \\
(1.071)\end{array}$ \\
\hline BIDASKDIF2 ${ }_{t}$ & $\begin{array}{l}(-47.777) \\
(21.132)\end{array}$ & $\begin{array}{l}-41.845^{\star} \\
(23.430)\end{array}$ & $\begin{array}{l}36.244^{* *} \\
(13.142)\end{array}$ & - & & $\begin{array}{l}28.100^{*} \\
(15.825)\end{array}$ \\
\hline USSPREAD $_{t}$ & - & - & - & - & & $\begin{array}{l}0.124 \\
0.053 \\
\end{array}$ \\
\hline LNDEBTGDP*USSPREAD ${ }_{t}$ & - & - & - & - & & \\
\hline ONOFFDIF $^{\star}$ USSPREAD ${ }_{t}$ & - & $\begin{array}{l}3.032^{*} \\
(1.638)\end{array}$ & $\begin{array}{c}-10.986^{* *} \\
(4.441)\end{array}$ & $\begin{array}{l}9.755^{\star *} \\
(4.590)\end{array}$ & & \\
\hline ONOFFDIF2 $^{*} U_{S S P R E A D_{t}}$ & $\begin{array}{c}10.160^{* *} \\
(4.590)\end{array}$ & $\begin{array}{c}-18.984^{* *} \\
(5.842)\end{array}$ & $\begin{array}{l}283.37^{\star \star} \\
(94.909)\end{array}$ & $\begin{array}{l}-279.22^{* *} \\
(94.959)\end{array}$ & & $\begin{array}{c}-16.634^{* *} \\
(3.344)\end{array}$ \\
\hline BIDASKDIF $^{*} U S S P R E A D_{t}$ & $\begin{array}{l}-3.358^{\star *} \\
(1.608)\end{array}$ & - & $\begin{array}{l}8.779^{\star \star} \\
(2.086)\end{array}$ & - & & $\begin{array}{l}7.353^{\star \star} \\
(1.635)\end{array}$ \\
\hline BIDASKDIF2*USSPREAD $_{t}$ & $\begin{array}{l}71.586^{\star \star} \\
(36.179)\end{array}$ & $\begin{array}{l}75.251^{* *} \\
(39.973)\end{array}$ & $\begin{array}{l}-85.035^{* *} \\
(25.838)\end{array}$ & $\begin{array}{l}79.203^{* *} \\
(33.831)\end{array}$ & $\begin{array}{c}-20.543^{* *} \\
(9.071)\end{array}$ & $\begin{array}{l}-51.382^{* *} \\
(23.851)\end{array}$ \\
\hline DPRE & $\frac{\gamma}{-}$ & & $\frac{\gamma}{-}$ & & $\begin{array}{c}\frac{\gamma}{0.125^{*}} \\
(0.075)\end{array}$ & \\
\hline CONSTANT & $\begin{array}{c}\alpha \\
0.283^{\star \star} \\
(0.063)\end{array}$ & & $\begin{array}{c}\alpha \\
0.556^{\star *} \\
(0.279)\end{array}$ & & $\begin{array}{c}\alpha \\
-0.286^{\star *} \\
(0.074)\end{array}$ & \\
\hline $\begin{array}{l}\text { Number of obs } \\
F(23,1461) \\
\text { Prob > F = }\end{array}$ & $\begin{array}{c}1485 \\
98.59 \\
0.00\end{array}$ & & $\begin{array}{c}1069 \\
135.93 \\
0.00\end{array}$ & & $\begin{array}{c}848 \\
200.56 \\
0.00\end{array}$ & \\
\hline
\end{tabular}

Prob $>\mathrm{F}=$

*Significant at 5 percent confidence level.

*Significant at 10 percent confidence level.

Standard Errors within parentheses 